\title{
Capturing agency in different educational settings: A comparative study on youth perceptions of mobility-framing structures
}

\author{
Tabea Schlimbach ${ }^{ \pm}$, Jan Skrobanek ${ }^{\ddagger}$, Emilia Kmiotek-Meier ${ }^{\propto}$, Volha Vysotskaya $^{\S}$
}

\begin{abstract}
The geographical mobility of young Europeans takes place within institutional realms that frame young people's educational and vocational situations. These institutional framings provide unequal preconditions for going abroad. Starting from an action-oriented theoretical approach, the aim of this work was to explore young people's international moves within different mobility settings. Based on 52 qualitative interviews with mobile youth from three mobility fields in three countries (students from Luxembourg, employees in Norway and Luxembourg and apprentices from Germany), the dynamic concept of context-sensitive mobility-related modes of action (MRMA) was developed. The applied analytic framework reflects the fact that individual perceptions and actions relating to going abroad differ greatly according to the young people's specific current educational/vocational situations. Moreover, the comparative approach sheds light on different dimensions of inequality caused by these framing systems.
\end{abstract}

Keywords: agency; structure; geographical mobility; inequality; student mobility; apprenticeship mobility.

\section{Introduction}

The mobility of European youth is a multifaceted phenomenon. Young people go abroad for various reasons: as part of their schooling or as apprentices; in order to study, to volunteer or to work; or just to gather new experiences. These mobilities are influenced by, and co-define, characteristics of contemporary youth such as individualisation (Heitmeyer et al., 2011), dissolution (Ferchhoff \& Dewe, 2016) and institutionalisation (Wehmeyer, 2016).

In connection with youth as a time of transition and as "educational moratorium" (Stecher, 2003; Zinnecker, 1991), youth mobilities are closely linked to vocational qualification. As a consequence of the educational penetration of youth, mobilities are aligned with the respective educational situations and regulatory institutional frameworks with which young people are involved at the time of their move abroad.

Inequality research in youth studies has been preoccupied mainly with the role of socioeconomic background, focusing for example on the availabilities of cultural, social and economic capital as well as personal characteristics (Bourdieu, 1983; Heinz, 2011; Zimmermann \& Skrobanek, 2015), the role of institutional frameworks (Möhring, 2016; Walther, 2006) or of economic conditions at the macro level (Hillmert et al. 2017; see also (Hemming et al., 2018 in this issue). High levels of variability in participation in mobility across mobility fields refer to another

\footnotetext{
${ }^{ \pm}$Tabea Schlimbach, German Youth Institute, Germany. E-mail: schlimbach@dji.de.

$¥$ Jan Skrobanek, University of Bergen, jan.skrobanek@uib.no.

${ }^{\propto}$ Emilia Kmiotek-Meier, University of Luxembourg, Luxembourg. E-mail: emilia.kmiotek@uni.lu.

$\S$ Volha Vysotskaya, University of Luxembourg, Luxembourg. E-mail: volha.vysotskaya@uni.lu.
} 


\section{Capturing agency in different educational settings}

dimension of inequality that feeds into the discussion around social inequality and education (Berger \& Kahlert, 2013). When young people consider going abroad, they are normally affiliated to certain educational stages that define specific mobility-framing institutional contexts and structural preconditions. These contexts form unique settings for individual experiences abroad. Thus not only individual resources but also the given and perceived opportunity structures of the respective educational systems affect individual mobility chances (Gerhards \& Hans, 2012). The youth mobility landscape in Europe shows unequal shares across different mobility fields such as student mobility, training mobility and employment mobility. While, for example, student mobility has been defined as part of a new map of European migration (King, 2002), vocational education and training (VET) represents a still uncommon field of mobility, with participation rates of about 3\% (European Commission, 2017).

Taking these considerations as a starting point, our aim is, firstly, to explore the variety of young people's actions in mobilities by contextualising them according to their institutional and biographical embedding. In doing so, we scrutinise how young people from different educational tracks perceive and respond to the respective settings and support structures that frame their mobilities. Using a comparative perspective, we also aim to understand how, from the perspective of the agency of mobile young people, unequal mobility opportunities evolve in different educational settings.

Comparison of how young people from different mobility fields move within these structures provides an opportunity to gain deeper knowledge of how inequalities between different fields are generated. Additionally, our comparative work (considering a wider range of mobility fields) contributes to a more comprehensive picture, countering the existing imbalances in youth mobility research in favour of highly skilled youth (Cairns et al., 2017).

\section{Background and Approach}

Youth mobility takes place at a certain time in life when developmental tasks such as gaining independence and developing a vocational perspective (Hurrelmann \& Quenzel, 2016; Lent et al., 1999; Stuhlmann, 2009) have to be tackled. This life course-specific transition period from education to work is a decisive marker for social integration (Leisering, 2004). Here, educational and training institutions frame the arrangements around these transitions to employment which jointly shape individual opportunities and frame the trajectories of the young (EGRIS, 2001).

The emphasis on young people's perspectives on mobility-framing institutional structures draws attention to agency as a sensitising concept (Evans \& Heinz, 1994; Furlong \& Cartmel, 1997; Pohl et al., 2011; Raithelhuber, 2008; Spencer \& Doull, 2015). In this context, individual actions and framing structures are understood as mutually constitutive elements (Emirbayer \& Mische, 1998) shaped by temporal, situational and social aspects (Biesta \& Tedder, 2006; Coffey \& Farrugia, 2013; Emirbayer \& Mische, 1998). Departing from this, we share an understanding of agency as something that is not opposed to structure, but that can be described as "young people's engagements with the conditions they face" (Coffey \& Farrugia, 2013: 472), and which implies the ability "'to make a difference,' that is, to exercise some sort of power" during the course of one's life (Giddens, 1984: 14).

Against this background, we assume that young people from different educational tracks perceive and respond differently to the respective educational settings and support structures that frame their mobilities. 


\section{Data and Methodology}

We draw upon data collected in the HORIZON 2020-funded research project MOVE, which addresses youth mobility in Europe. Our qualitative study comprised case studies in six mobility fields, based on problem-centred interviews (Witzel \& Reiter, 2012) with (formerly) mobile young people. For this paper, a subsample of qualitative cases in the mobility types immediately connected to vocation-related transitions (employment, tertiary education and vocational training) was selected for three countries (Germany, Luxembourg and Norway). The dataset altogether comprising 52 interviews with young people aged between $18-29$ years: 12 outgoing higher education (HE) students from Luxembourg, 12 incoming employees in Norway; 13 incoming employees in Luxembourg; 15 outgoing apprentices from Germany. In the sample, interviews of both outgoing and incoming people were included according to the way in which they are characteristic for the particular mobility fields and countries. The chosen mobility types vary with regard to the degree of structuration, thus ranging from more structured (VET) to more open (employment) frames. Adopting a cross-field perspective on European youth mobility - while remaining sensitive to variations between countries - allows us to highlight the differences and similarities of modes of agency under varying structural settings across the three mobility types.

The exploratory approach comprised key sequence analyses of agency-related, biographyrelated and structure-related codes such as experience, uncertainty, choice, decision, opportunities, constraints, and mobility practices. Moreover, cross-case and cross-field comparisons (Miles \& Huberman, 1984) were used to identify variations in modes of agency. The inequality issue was carved out inductively by looking for "core themes" (Bernard et al., 2017).

\section{Results}

To better locate the results obtained, we firstly introduce the specifics and institutional framings of the respective mobility field. Secondly, we examine the mobility-related action(s) of students, apprentices and employees. Thirdly, we introduce context-sensitive mobility-related modes of action (MRMA) as a suggestion for a dynamic concept to capture mobility-related youth agency. In a fourth step, in order to address the question of unequal opportunities provided by mobility-framing educational settings, we compare these fields in terms of the latitude they allow and restraints they place on young people's agency.

\section{Mobility-framing structures}

Three vocational strands have been analysed in three particular national contexts which form unique settings for young people's individual moves. These settings are examined firstly in order to understand mobility experiences in their respective embeddedness.

\section{HE student mobility (outgoing students from Luxembourg)}

In Luxembourg, education abroad was the only option for obtaining a university degree until the foundation of the country's first public university in 2003. One of the requirements for undergraduates at the University of Luxembourg (UL) is a compulsory semester abroad. Thus almost all Luxembourgish students have studied abroad as part of the study programme at the UL (credit mobility) or have completed a full study programme abroad (degree mobility). The UL provides organisational support and has bilateral contractual agreements with foreign universities. Degree mobility is less regulated than credit mobility and is largely self-organised, with Luxembourg having the highest numbers of outgoing degree students worldwide (OECD, 2014). 
The national information centre (CEDIES) and the association of Luxembourgish students abroad (ACEL), both originally designed for degree students, are being used as a source of information on a stay abroad by both groups. All mobile students are entitled to a mobility allowance in addition to their student allowance.

\section{VET mobility (outgoing apprentices from Germany)}

In contrast to student mobility and employment mobility, going abroad as apprentice is still a rare phenomenon. In this field, Germany can be seen as role model. While in most European countries, VET is subordinate to tertiary education, the German VET system has a long-standing tradition and is regarded worldwide as a model of success, being characterised by high standards and close alignment to the economy (Ebner \& Uhly, 2016). Fitting in with the rigid structure of a segmented apprenticeship market and tight curricula, stays abroad are largely organised as shortterm group moves within the Erasmus ${ }^{+}$programme which are facilitated by mobility advisors (Schlimbach \& Hemming, 2018). These experts are organised in a nationwide network which is unique in Europe. The National Agency for Education in Europe at the Federal Institute for Vocational Education and Training (NABIBB) is responsible for the coordination of Erasmus + mobilities in the VET field.

\section{Employment mobility (incoming employees in Norway and Luxembourg)}

Norway's attractiveness for incoming employment mobility can be explained by its high standards and regulation of the labour market, a favourable economic situation (for example, having the lowest youth unemployment rate in Europe, about 11\%, in 2016 (OECD, 2017), good living prospects and low social inequality (see Hemming et al., 2019 in this issue). This has resulted in unparalleled labour and service mobility of young people, especially from Eastern Europe following the eastern expansion of the EU, but also from western EU countries. Luxembourg is a country of immigration with a long-standing history of welcoming working people from neighbouring and other countries. The country's economy is constantly growing (with the largest GDP in the EU) and migrant labour has formed part of its backbone.

Compared to other vocation-related types of mobility, funding opportunities for employment mobility among young people are rather narrow. The main programme designed for this purpose is first EURES job (with limited applicability due to age restrictions, employment status and sometimes skills). Consequently, employment mobilities undertaken within EU schemes remain low, in both countries. Furthermore, youth mobility in this field is largely self-organised, being left to young people's personal capacities and networks to overcome barriers.

\section{"Mobilities structuration" in respect of the three mobility fields}

The three mobility settings differ greatly in terms of institutional/legal standards and frameworks. Student mobility in Luxembourg is forced (Kmiotek-Meier \& Karl, 2017), resulting from a long tradition of student mobility, and is generously supported by the state. VET mobilities of German apprentices are largely designed as short-term group mobilities and are managed institutionally, in order to harmonise them with the rigid, standardised German VET system. Employment mobilities are individual undertakings which themselves are hardly regulated; however, they are greatly influenced by the economic and employment situation in the home and destination countries. 


\section{Field-sensitive agency responses}

\section{HE student mobility (outgoing students from Luxembourg)}

In Luxembourg, one can speak of a national tradition of educating young people abroad (Kmiotek-Meier \& Karl, 2017; Kmiotek-Meier et al., 2018). Mobility is written into the tertiary education trajectory. Among the interviewees, a stay abroad in the course of study is perceived as "normal":

"That's why for me there was never a question of studying in Luxembourg; it was just totally normal to study abroad." (Celine, Luxembourgish degree student in Austria)

This individually perceived "normality" or "norm" of going abroad is transformed by Luxembourgish students in manifold ways, which can be illustrated by the example of the choice of destination country. This choice depends on individual possibilities and emphases e.g. regarding proximity (especially for those who feel they are institutionally forced to be mobile) versus distance (for those aiming at independence and adventure), the placement list of the university or the spoken language (with different accents on personal language capabilities or the requirements of the future profession):

"Now you know why neither Germany nor Austria came into my mind before [...] French is important here, on the labour market [...] It is because it would have not been that good to do it in German." (Lucas, Luxembourgish credit student in France)

Students from Luxembourg are confronted with a unique structural requirement: a decision to study involves the obligation to move abroad for at least one semester. Consequently, individual considerations and decisions are rather related to the "how" instead of the "if" of going abroad. Firstly, students can opt to study for a degree abroad, or they can stay at home and become a credit student. Secondly, they can decide where and with whom to go. Hence, while students from Luxembourg have no room to manoeuvre between the two options of "mobility" and "immobility", they gain degrees of freedom with regard to the range of mobility options and the individual interpretation, adaptation and transformation of the structural imperative of becoming mobile during their study. Moreover, the University of Luxembourg, as a new institutional player, has reshaped the latitude of agency of mobile Luxembourgish students, emphasising that the organisational regulation of the field does matter in the process of going aboard.

While most students appreciate mobility as a privilege, and acknowledge its relevance for promoting their careers and for personal development, credit mobility is seen by some students as a burden (Kmiotek-Meier \& Karl, 2017):

"So I also do not understand why it is an obligation here, why [the University of

Luxembourg] thinks it must send everybody abroad. (...) I do not understand it. I still think it is not a good idea to force us (...) even though I had a good experience." (Henriette, Luxembourgish credit student in Germany)

In most cases the stay abroad - be it as a credit or a degree student - is linked to ideas of independence and autonomy, indicating the transitional character of the stay abroad during tertiary 


\section{Capturing agency in different educational settings}

education. Paradoxically, the forced stay abroad was seen by many credit students as a hindering factor, despite the fact that it offered an opportunity to gain independence (see also Kmiotek-Meier et al., 2019 in this issue). A recurring topic in the interviews was the eagerness to stand on one's own feet, including taking responsibility for down-to-earth matters such as grocery shopping or paying the rent on time. The fact that many mobile students still somehow depended on financial or instrumental help from their parents or the state in the course of their stay abroad, however, marks this period of life as a preliminary stage before full adulthood.

\section{VET mobility (outgoing apprentices from Germany)}

German apprentices have been largely unaware of VET as a mobility field prior to their experiences abroad, and they became mobile mostly as a result of external prompting from teachers and mobility advisors. In the minds of German apprentices, VET mobility appears as an opportunity structure, and if it is connected with vocational aspects, the aims are rather exploratory, such as gaining work experience and experiencing alternative ways of training and working. More dominantly, however, it is perceived as a unique and cost-effective opportunity to explore a new country and culture.

"I just thought it was great, that it was so simple (.) for four weeks, that you could just go there so easily [...], that you can just say I don't have to rent a hotel here [...] there are projects for it, that's superb [...] You always have a point of contact, uh (.) yes, it is all organised for you

[...] and to get there for so little money" (Helena, a German apprentice who went to Ireland)

Moreover, short-term group mobilities which are typical for German VET mobility are appreciated as a "convenient" way to go abroad, involving low effort, risk and insecurities (Reiter $\&$ Schlimbach, 2015). Young people readily and spontaneously accept invitations to take part in the programme, under the condition of guidance. They greatly appreciate, and rely upon, the support of institutional actors. Mobility advisors embody a set of key functions in VET mobilities: they work as gatekeepers, since they approach and select young people (often based on meritorious performance in school); they guide them through administrative procedures, relieve them of bureaucratic efforts and cushion them against challenges. A similar function is ascribed to peers travelling abroad together in groups, where they function as a safety net, as they reduce insecurity and create familiarity:

"We found out about it through the school; we were asked who was interested in going to Finland [...]. Yeah, so I just decided for myself that I wanted to do it because it's also a good opportunity. I probably wouldn't have done it alone; I mean I'd say I probably wouldn't have thought of it. And because I had a few of my classmates with me who also wanted to do it, we [...] were also lucky enough to be able to go together." (Vanessa, German apprentice in Finland)

Tasks and challenges that accompany the move abroad can be shared among the travelling peers. This involves engaging in practices typically associated with adulthood (e.g. living independently from parents, housekeeping and managing the household budget) which take place in the protected environment of the compatriot group. However, retrospectively, hindering group effects are also reported: one's companions from home can function as barriers to the culture and 
the people of the host country (corresponding with results from Ardic et al., 2018), and leave less space for individual learning and growing up.

The latitude afforded to young people in the context of VET mobility seems rather narrowly framed in comparison with that for students and employees, being strongly guided and structured by VET-specific "mobility handrails". Individual actions are inspired and directed to a great extent by accompanying institutional actors and peers. Thus, VET mobilities might appear from the outside to be structurally dictated, predefined and guided mobilities rather than individual arrangements. However, this is not reflected in the individual recollections of the apprentices. In fact, mobility is perceived as personal achievement, as a well-earned reward for their own efforts. At the same time, the (seemingly) all-embracing institutional arrangements are not reported to be restraints, but to be convenient, and are often even seen as a fundamental precondition for their readiness to move.

\section{Employment mobility}

Unlike other vocation-related mobility types, in employment mobility young people hardly rely on EU-funded or state-funded programmes. If they do, one form is to utilise programmes designed for educational purposes as a point of entry to employment abroad (through a two-step migration). This shows the creative exploitation of funding regulations in favour of opportunity windows in one's own biography (such as finishing education), leading to disguised forms of employment mobilities:

"I had already finished my studies, I was over 25 and of all the projects I could choose to go abroad without spending any money was the EVS, because I did not have money and it was the fastest one." (Lisa from Spain, working in Norway)

However, as our data indicates, company-based activities (company programmes, job offers through job advertisements or recruitment companies) or individually organised moves are more common, which demand information management, purposeful self-advertisement and proactive application:

"Three big firms, multinationals, they were really interested in people with an international profile, who have studied [international law] [...] Well, I know their problems finding and recruiting people in Luxembourg for those positions, so this is how I got contacted and how I got recruited." (Thomas, Belgian, working in Luxembourg)

Young employees exploit their own economic and social capital. Informal networks (friends and family and, increasingly, digital networks such as mobility-related Facebook groups for various nationals) play an important role in landing a job abroad and in overcoming the pitfalls with regard to mobility:

"Uh, just for the sake of clarity, my sister is head of [advertising] in that agency [A in Italy]. So you know, connections, again." (Leonardo, Italian, working in Luxembourg).

In contrast to HE student and VET mobilities, going abroad for employment purposes takes place at a (biographically) later stage, more into adulthood. Here, the timing and duration of 


\section{Capturing agency in different educational settings}

mobility is more flexible and, as stated above, dependent on individual "mobility windows", which can be understood as favourable life moments (job flexibility, prior to or after having children, completion of an educational track/transitions to work, mobility of the partner, unemployment). The decision to go abroad marks a biographical turning point. Employees on the move often describe their experiences as highly autonomous processes outside programmes and largely unassisted by organisations, which indicates the detachment from formal educational frameworks. Mobility is perceived as an independent, adventurous, sometimes risky individual action and is used as a platform for exercising adult practices (Cuzzocrea \& Magaraggia, 2013; Pitti, 2017). The young people aim at personal development through new biographical experiences and challenges. At the same time, mobility is seen as a route to employment and, mediated through this, as a chance to improve quality of life (security, economic wealth):

"I think it will be easier in Norway, I suppose, to get to the places we want to be faster; we can save up money here, and we can maybe build a house..." (Nika from Iceland, working in Norway)

Mobility-related decision-making in this group is dominated by the idea of labour market integration and sometimes as an escape from a biographical dead end. This results in adaptive behaviour towards perceived labour market options.

Again, the choice of the destination country is meaningful. Aside from economic considerations and personal development, it is based on positive connotations of country-specific characteristics. Norway for example is connected with ideas of an adventurous, solitary life that is close to nature. In Anna's case, it is at the same time entangled with childhood remembrances:

"Yes, actually when I was child, the only travelling I did was to Norway [...] I remember these big mountains and this ... when we were hiking and he-yeah ... I always really liked Norway ... it was my early memories and wish to return."

(Anna from Estonia, working in Norway)

Luxembourg, however, is often chosen due to its spatial proximity, profiting from an advantageous geographic position in the centre of western Europe, and from the crossroads of German-French cultures and traditions (Chauvel, 2016). Moreover, Luxembourg is attractive as an international hub with multinational companies, EU institutions, and linguistic diversity.

Mobile employees make use of the labour market opportunities of different countries, and take into consideration national particularities and histories. In comparison with the other fields under examination, employment mobilities represent unique, individualised mobility settings, and the employees exhibit higher levels of autonomy and proactivity. Moreover, employment mobility is a field where the entanglement with the young people's individual biographies is strongly visible, e.g. through the need of a favourable biographical timeslot for going abroad (e.g. after finishing education), the consideration of the current family situation (e.g. the children's educational stage, the partner's employment situation) or the choice of the destination country with reference to former travel experiences or to personal contacts (friends, family) abroad.

To sum up, students, apprentices and young employees not only have different perceptions and aims connected with going abroad, they also have to deal with a completely different set of mobility- 
framing institutional actors and factors which, to add to the complexity, are highly specific to each country. Mobile youth show vital, multifaceted responses to these unique framings.

\section{MRMA: the field-sensitive agency of mobile youth}

To date, approaches to capturing agency in youth research (especially in the context of transitional research) have resulted in the development of various typologies which, amongst other aspects, differ according to the nuances regarding the constancy versus convertibility/transformation/change of youth agency across space and time. They range from an idea of agency as something young people possess to different degrees and which is "bounded" by structures (Evans, 2007), to active patterns of transitional/career movements/transition behaviours (Evans \& Heinz, 1994), to contextually activated orientation and action patterns (Witzel \& Kühn, 1999), or to the "capacity of making choices" (Skrobanek \& Ardic, 2016).

Our individual case analyses as well as case comparisons within three mobility fields (higher education, vocational training, and employment) indicate that young people's mobility-related reflections and actions vary depending on how the young perceive the situation, how they interpret given institutional degrees of freedom and how they adapt to temporal, mobility-framing structural characteristics. As the cross-field comparison has revealed, individual agency is sensitive to the respective structural embeddedness that is tied to the overall educational and vocational setting in which young people's mobility takes place.

Thus, the empirical material calls for a dynamic understanding of agency which responds to changing educational and national mobility-framing contexts. Based on our analysis of young people's mobility-related understanding and behaviour, we propose the concept of context-sensitive mobility-related modes of action (MRMA). This concept is neither a static typology, nor is it limited to what people actually do, but includes young people's dynamic reflections and plans that frame their mobility-related manoeuvring within the context in which they take place. Thus MRMA embrace young people's perceptions, interpretations and transformations of, and adaptations to, different mobility-framing structural characteristics.

The MRMA are shown to vary according to the respective circumstances in which mobilities take place, and are sensitive to the following, closely interrelated structural and temporal dimensions:

- the vocational setting in which the mobility is embedded (mobility type),

- the mobility-framing institutional structures,

- the overall biographical embeddedness.

However, aside from these specifics, our analysis underlines substantial cross-field commonalities in MRMA, which are often rooted in a desire to reduce insecurity, anxiety and effort (Reiter \& Schlimbach, 2015). These modes include intensive use of networks and opportunity structures. Moreover, country choices, if not institutionally determined, are made on the basis of positive connotations that match individual goals and preferences. Not least, young mobile people from all fields share a retrospective assessment of mobilities as valuable (learning) experience, with the potential to lead to concatenations of mobility.

\section{Areas of Inequalities}

Mobility-framing educational settings provide varying levels of latitude for youth agency, and lead to situationally adjusted, field-specific responses. However, the agentic capacity revealed in 


\section{Capturing agency in different educational settings}

the interviews cannot hide the fact that young people face field-dependent inequalities which jointly shape their mobility opportunities. Our data indicates four main areas of inequalities:

- Mobility cultures: This area relates to the establishment level of educational/ vocational settings as mobility fields, and takes into consideration the frequency of going abroad in these fields, the level of respective knowledge concerning opportunities to move, and the standards that are established regarding mobilities. The awareness of mobility opportunities in educational settings, as well as traditions of mobility influence young people's readiness to move. As our Luxembourg case reveals, HE student mobility is well known and can be seen as part of student culture. In contrast, there is little knowledge about mobility opportunities among apprentices, which makes external stimuli decisive for initiating a move in the context of VET.

- Institutional support: This area refers to the availability and quality of support in a certain field. Closely connected to field-specific traditions of mobility and modes of implementation, support structures vary significantly in terms of their availability and appropriateness to individual needs. For HE students from Luxembourg and for German apprentices who nurture the idea of becoming internationally mobile, well-established, institutionalised help is available (though unequally distributed in Germany), while moving for employment purposes is largely self-organised and the supportive role often falls to family members or friends.

- Access to mobility funds: While all young Europeans can, in principle, make use of European funds, inequalities at the threshold to mobility arise through their dependency on a certain status (e.g. being a student) and through differing national practices regarding implementation of the programmes. In Germany, the selection of apprentices by mobility advisors, which is mostly performance-based, discriminates against those who did not succeed in getting a training place, or those with poor grades. Moreover, for German VET students, the training companies are gatekeepers, as their approval is a precondition for such moves. Luxembourgish HE students, however, experience positive discrimination compared to other young Europeans, as they are entitled to mobility scholarships during their studies, and mobility (credit or degree mobility) is an obligation. Employment mobility, finally, takes place in a "funding vacuum" compared with other mobility fields, with little money explicitly offered to those looking for employment. Going abroad to work is treated as responsibility of the individual.

- Mobility windows/temporality: The structuring of respective educational paths provides mobility windows to different extents. While for Luxembourgish credit students, one academic semester is envisaged for stays abroad, the rigid syllabus of the German VET system only allows a few weeks of interruption without consequences for the overall duration of the vocational training. In employment mobility, the problem of finding the right moment to move is highly individualised and depends on favourable biographical timing; moreover, the end of the stay abroad is often not predetermined, but open to dynamic individual goal setting in the course of the stay.

- Rooms to manoeuvre vs. institutional penetration: The analysis indicates varying degrees of inequalities regarding the latitude available to young people and the constraints on their ability to actively shape their own mobility experiences, e.g. by (co-)determining the destination country, the place of work/education, the time and duration, and the 
activities once there. For VET mobility in Germany as well as credit student mobility in Luxembourg, which mostly take place soon after schooling has been completed, features of mobility (e.g. destination, timing and duration) are largely institutionally predefined. One could argue in two directions: that these embracing structures are adapted to the needs and insecurities expressed by these (very) young people regarding the move abroad, or that the rigid educational embeddedness of apprentices and $\mathrm{HE}$ credit students requires standardised mobility procedures. Degree and employment mobilities in Luxembourg and Norway provide for greater latitude, demanding a lot more individual initiative and autonomous decision-making. Employment mobility is the least regulated field, allowing highly individual, unique mobility experiences, but leaving movers largely alone in terms of organisation and risk management.

When re-connecting these areas of inequalities to the individual sphere, the respective national and educational frames of mobility experiences appear as different agency-framing mobility systems: for example, in credit mobility in Luxembourg and VET mobility in Germany, as "guiding systems" (allowing low levels of autonomy, decision making and proactivity), in student mobility in Luxembourg as "forcing systems" (national tradition to study abroad as a point of reference for degree students; institutionally induced mobility windows for credit students) and in employment mobilities, as "detaching systems" (with low institutional constraints, freedom to manoeuvre and an individualisation of risks). Considering the diversity of national systems in the respective fields, these can be seen as ideal-type examples while manifold other constellations demand for specifications.

\section{Summary and Discussion}

The objective of this work has been to understand young people's mobility-related agency in accordance with the respective educational/vocational fields in which the moves take place. Moreover, we have approached the question of unequal mobility opportunities across these fields on a micro-level. The analysis concerning the first aim shows that young people from different fields deal with diverse institutional contexts. They do this in multifaceted, creative ways which show that economic considerations, but also peer and family encouragement, striving for autonomy, self-development, longing for adventure, and, not least, convenience, are powerful in mobilityrelated decision making (in line with quantitative results, see for example Cairns \& Smyth, 2010; Hemming et al., 2018 in this issue). To account for the highly individual responses according to the vocational situation within which the mobility takes place, we propose the dynamic concept of context-sensitive mobility-related modes of action (MRMA). The MRMA model reveals not only the interplay of specific institutional contexts and individual action; it also shows how mobilities are intertwined with personal biographies. This appears especially strong in employment mobilities.

Using a comparative perspective, we have analysed how, from the point of view of the agency of mobile youth, unequal mobility opportunities evolve in different educational settings. The analysis reveals that young people face unequal starting points with regard to mobility, resulting from varied opportunity structures depending on their current biographical status. Different opportunities arise from particularities of different educational fields and respective mobility practices (e.g. mobility cultures, time slots and room to manoeuvre) which, with reference to the young people's mobility-related acting, form framing systems of guiding, forcing or detaching character. While mobilities are actively used as instruments to foster transitions to 


\section{Capturing agency in different educational settings}

adulthood and employment, inequalities across educational settings regarding participation in mobility sustain the disparities which already exist with regard to access to these positions (Lörz, 2013).

The results reinforce theoretical characterisations of agency as situationally, temporally and socially dynamic. Moving beyond micro- and macro-economic explanations (e.g. by Hemming et al., 2016; Netz \& Finger, 2016; Ohnmacht et al., 2009) this comparative work sheds light on the individual sphere of the heterogeneity of the phenomenon of the mobility of European youth. It explores the variety of young people's mobility-related action by contextualising them according to their institutional and biographical settings. It considers a wider range of mobility fields, thus contributing to a more comprehensive picture of the landscape of the mobility of European youth.

However, this research has to be seen as a starting point. In order to delve deeper into the diversity of youth mobility in Europe and to better understand how young people move within different opportunity structures across countries and mobility fields, the scope of analysis has to be extended to further countries (covering a wider range of economic and social systems) and other fields (such as volunteering mobility or entrepreneurship). Moreover, including non-mobiles in the sample can shed light on the obstacles that these frames produce. More research is also needed on the entanglements of experiences abroad in the young people's biographies, where a longitudinal research design (capturing the young people's perceptions at different times before, during and after the mobility) would be highly beneficial.

\section{References}

Ardic, T., Pavlova, I., \& Skrobanek, J. (2018). Being international and not being international at the same time: the challenges of peer relations under mobility. In H. Hogset, D. M. Berge, \& K. Y. Dale (Eds.), Fjordantologien 2018. Universitetsforlaget. https://doi.org/10.18261/9788215031224-2018-12

Berger, P. A., \& Kahlert, H. (Eds.). (2013). Institutionalisierte Ungleichheiten: Wie das Bildungswesen Chancen blockiert (3. Auflage). Bildungssoziologische Beiträge. Weinheim: Beltz-Juventa. Retrieved from http://www.socialnet.de/rezensionen/isbn.php?isbn=978-3-7799-1590-4

Bernard, H. R., Wutich, A., \& Ryan, G. W. (2017). Analyzing qualitative data: Systematic approaches (Second edition). Los Angeles, London, New Delhi, Singapore, Washington DC, Melbourne: Sage.

Biesta, G., \& Tedder, M. (2006). How is agency possible? Towards an ecological understanding of agencyas-achievement. (Working Paper). Retrieved from

https://www.researchgate.net/profile/Michael_Tedder/publication/228644383_How_is_agency_possible _Towards_an_ecological_understanding_of_agency-as-

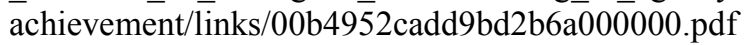

Bourdieu, P. (1983). Ökonomisches Kapital, kulturelles Kapital und soziales Kapital. In R. Kreckel (Ed.), Soziale Ungleichheiten (pp. 183-198). Göttingen: Otto Schwartz \& Co.

Cairns, D., \& Smyth, J. (2010). Youth on the move? Student mobility and immobility in Portugal and Northern Ireland. In D. Cairns (Ed.), Beiträge zur Regional- und Migrationsforschung. Youth on the Move: European Youth and Geographical Mobility (pp. 59-70). Wiesbaden: VS Verlag für Sozialwissenschaften / GWV Fachverlage GmbH Wiesbaden. https://doi.org/10.1007/978-3-531-923314_6

Cairns, D., Cuzzocrea, V., Briggs, D., \& Veloso, L. (2017). The Consequences of Mobility: Reflexivity, Social Inequality and the Reproduction of Precariousness in Highly Qualified Migration. Cham, s.l.: Springer International Publishing. https://doi.org/10.1007/978-3-319-46741-2 
Chauvel, L. (2016, December). La Spirale du Déclassement - Essai sur la Société des Illusions. La Bibliothèque nationale de Luxembourg, Luxemburg.

Coffey, J., \& Farrugia, D. (2013). Unpacking the black box: The problem of agency in the sociology of youth. Journal of Youth Studies, 17(4), 461-474. https://doi.org/10.1080/13676261.2013.830707

Cuzzocrea, V., \& Magaraggia, S. (2013). Blurred Transitions: Revisiting the Importance of Work and Parenthood for Young Adults in Italy. In A. Nicolas \& I. Flaherty (Eds.), Growing Up and Growing Old: Trajectories of Times and Lives (pp. 63-87). Oxford: Interdisciplinary Press.

Ebner, C., \& Uhly, A. (2016). Entstehung und Merkmale des dualen Ausbildungssytems. Retrieved from http://www.bpb.de/gesellschaft/kultur/zukunft-bildung/228394/entstehung-und-merkmale

Emirbayer, M., \& Mische, A. (1998). What Is Agency? American Journal of Sociology, 103(4), 962-1023. https://doi.org/10.1086/231294

European Commission. (2017). Progress report on a Learning Mobility Benchmark (No. COM(2017) 148 final). Brussels.

European Group for integrated social research (EGRIS). (2001). Misleading Trajectories: Transition Dilemmas of Young Adults in Europe. Journal of Youth Studies, 4(1), 101-118. https://doi.org/10.1080/13676260120028574

Evans, K. (2007). Concepts of bounded agency in education, work, and the personal lives of young adults. International Journal of Psychology, 42(2), 85-93. https://doi.org/10.1080/00207590600991237

Evans, K., \& Heinz, W. R. (Eds.). (1994). Becoming Adults in England and Germany.

Ferchhoff, W., \& Dewe, B. (2016). Entstrukturierung und Entgrenzung der Jugendphase. In U. Becker, H. Friedrichs, F. von Gross, \& S. Kaiser (Eds.), Ent-Grenztes Heranwachsen (1st ed., pp. 31-50). Wiesbaden: Springer VS. https://doi.org/10.1007/978-3-658-09793-6_2

Furlong, A., \& Cartmel, F. (1997). Young People and Social Change: Individualization and Risk in Late Modernity. Rethinking Ageing Series. Maidenhead: Open University Press.

Gerhards, J., \& Hans, S. (2012). Transnationales Bildungskapital und soziale Ungleichheit (Berliner Studien zur Soziologie Europas / Berlin Studies on the Sociology of Europe (BSSE) No. 25).

Giddens, A. (1984). The constitution of society: Outline of the theory of structuration (1. publ). Berkeley: Univ. of Californai Press.

Heinz, W. R. (2011). Jugend im gesellschaftlichen Wandel: soziale Ungleichheiten von Lebenslagen und Lebensperspektiven. In E. M. Krekel \& T. Lex (Eds.), Berichte zur beruflichen Bildung. Neue Jugend, neue Ausbildung? Beiträge aus der Jugend- und Bildungsforschung (pp. 15-30). Bielefeld: Bertelsmann.

Heitmeyer, W., Mansel, J., \& Olk, T. (2011). Individualisierung heute: Verdichtung und Vernichtung? In W. Heitmeyer (Ed.), Jugendforschung. Individualisierung von Jugend: Zwischen kreativer Innovation, Gerechtigkeitssuche und gesellschaftlichen Reaktionen (pp. 7-25). Weinheim u.a.: Beltz Juventa.

Hemming, K., Schlimbach, T., Tillmann, F., Nienaber, B., Roman, M., \& Skrobanek, J. (2018). Structural framework conditions and individual motivations for youth-mobility: A macro-micro level approach for different European country-types. Migration Letters, 16(1), pp.45-59. https://doi.org/10.33182/ml.v16i1.621

Hemming, K., Tillmann, F., \& Reißig, B. (2016). Final Work Package Report WP2: Sampling and secondary analyses of macro data of youth mobility in Europe and the partner countries. Public Report. Halle. Retrieved from http://move-project.eu/reports-publications/

Hillmert, S., Hartung, A., \& Weßling, K. (2017). A Decomposition of Local Labour-Market Conditions and Their Relevance for Inequalities in Transitions to Vocational Training. European Sociological Review, 33(4), 534-550. https://doi.org/10.1093/esr/jcx057

https://doi.org/10.1787/c3634df7-en 


\section{Capturing agency in different educational settings}

Hurrelmann, K., \& Quenzel, G. (2016). Lebensphase Jugend: Eine Einführung in die sozialwissenschaftliche Jugendforschung (13., überarbeitete Auflage). Grundlagentexte Soziologie. Weinheim, Basel: Beltz Juventa. Retrieved from http://www.contentselect.com/index.php?id=bib_view\&ean=9783779945161

King, R. (2002). Towards a new map of European migration. International Journal of Population Geography, 8(2), 89-106. https://doi.org/10.1002/ijpg.246

Kmiotek-Meier, E. A., \& Karl, U. (2017). Being forced? Getting far? Speaking the language? What matters in the process of going abroad as a student? Space and Society. (31 (4)), 90-104.

Kmiotek-Meier, E., Karl, U., \& Powell, J. J. W. (2018). Designing the (Most) Mobile University: The Centrality of International Student Mobility in Luxembourg's Higher Education Policy Discourse. Higher Education Policy, 25(5), 107. https://doi.org/10.1057/s41307-018-0118-4

Kmiotek-Meier, E., Skrobanek, J., Nienaber, B., Vysotskaya, V., Samuk, S., Ardic, T., .. Horvath, K. (2018). Why is it so hard? And for whom? Obstacles to intra-European mobility Migration Letters, 16(1), pp.31-44. DOI: https://doi.org/10.33182/ml.v16i1.627

Leisering, L. (2004). Government and the Life Course. In J. T. Mortimer \& M. J. Shanahan (Eds.), Handbooks of sociology and social research. Handbook of the life course (pp. 205-225). New York: Springer.

Lent, R. W., Hackett, G., \& Brown, S. D. (1999). A Social Cognitive View of School-to-Work Transition. The Career Development Quarterly, 47(4), 297-311. https://doi.org/10.1002/j.21610045.1999.tb00739.x

Lörz, M. (2013). Differenzierung des Bildungssystems und soziale Ungleichheit: Haben sich mit dem Ausbau der beruflichen Bildungswege die Ungleichheitsmechanismen verändert? / Differentiation in Higher Education and Social Inequality: Have the Mechanisms of Social Inequality Changed with the Expansion of Vocational Education? Zeitschrift Für Soziologie, 42(2), 61. https://doi.org/10.1515/zfsoz2013-0204

Miles, M. B., \& Huberman, A. M. (1984). Qualitative data analysis: A sourcebook of new methods. Beverly Hills: Sage Publ. Retrieved from http://www.loc.gov/catdir/enhancements/fy0654/84002140-d.html

Möhring, K. (2016). Life course regimes in Europe: Individual employment histories in comparative and historical perspective. Journal of European Social Policy, 26(2), 124-139. https://doi.org/10.1177/0958928716633046

Netz, N., \& Finger, C. (2016). New Horizontal Inequalities in German Higher Education? Social Selectivity of Studying Abroad between 1991 and 2012. Sociology of Education, 89(2), 79-98. https://doi.org/10.1177/0038040715627196

OECD. (2014). Education at a Glance 2014: OECD Indicators. Paris: OECD Publishing. Retrieved from http://gbv.eblib.com/patron/FullRecord.aspx?p=1825936

OECD. (2017). Youth unemployment rate (indicator). Retrieved from https://doi.org/10.1787/c3634df7-en

Ohnmacht, T., Maksim, H., \& Bergman, M. M. (2009). Mobilities and Inequalities. Farnham: Ashgate.

Pitti, I. (2017). What does being an adult mean? Comparing young people's and adults' representations of adulthood. Journal of Youth Studies, 20(9), 1225-1241.

https://doi.org/10.1080/13676261.2017.1317336

Pohl, A., Stauber, B., \& Walther, A. (Eds.). (2011). Jugend als Akteurin sozialen Wandels: Veränderte Übergangsverläufe, strukturelle Barrieren und Bewältigungsstrategien. Jugendforschung. Weinheim: Juventa-Verlag. Retrieved from http://www.socialnet.de/rezensionen/isbn.php?isbn=978-3-7799-1757-1

Raithelhuber, E. (2008). Von Akteuren und agency: Eine sozialtheoretische Einordnung der structure/agency-Debatte. In H. G. Homfeldt, W. Schröer, \& C. Schweppe (Eds.), Vom Adressaten zum Akteur: Soziale Arbeit und Agency (pp. 17-45). Opladen: Barbara Budrich. 
Reiter, H., \& Schlimbach, T. (2015). NEET in disguise? Rival narratives in troubled youth transitions. Educational Research, 57(2), 133-150. https://doi.org/10.1080/00131881.2015.1030851

Schlimbach, T., \& Hemming, K. (2018). Was fördert, was hindert Jugendmobilität? Chancen und Risiken deutscher Mobilitätspraktiken. In J. Lange (Ed.), Loccumer Protokolle: 66/2017. Jugendmobilität als europäische Strategie - Wer und was bewegt Jugendliche? (pp. 35-42). Hildesheim/Rehburg-Loccum.

Skrobanek, J., \& Ardic, T. (2016). Agency, choice and structure in young people's mobility: Reflections on a missing link. Revista De Estudios De Juventud Injuve. (113), 39-52.

Spencer, G., \& Doull, M. (2015). Examining concepts of power and agency in research with young people. Journal of Youth Studies, 18(7), 900-913. https://doi.org/10.1080/13676261.2014.1001827

Stecher, L. (2003). Jugend als Bildungsmoratorium — die Sicht der Jugendlichen. In H. Reinders \& E. Wild (Eds.), Jugendzeit - Time Out? Zur Ausgestaltung des Jugendalters als Moratorium (pp. 201-217). Wiesbaden, s.1.: VS Verlag für Sozialwissenschaften. https://doi.org/10.1007/978-3-322-97603-1_10

Stuhlmann, K. (2009). Die Realisierung von Berufswünschen - Durch die Identitätsentwicklung im Jugendalter vorhersagbar? In H. Fend, F. Berger, \& U. Grob (Eds.), Lebensverläufe, Lebensbewältigung, Lebensglück: Ergebnisse der LifE-Studie (1st ed., pp. 73-99). Wiesbaden: VS Verlag für Sozialwissenschaften / GWV Fachverlage GmbH Wiesbaden. https://doi.org/10.1007/978-3531-91547-0_3

Walther, A. (2006). Regimes of youth transitions: Choice, flexibility and security in young people's experiences across different European contexts. Young. (14 (2)), 119-139. https://doi.org/10.1177/1103308806062737

Wehmeyer, K. (2016). Entgrenzung, Individualisierung, Institutionalisierung - Eine Jugend im Wandel. In U. Becker, H. Friedrichs, \& F. von Gross (Eds.), Ent-Grenztes Heranwachsen (pp. 51-69). https://doi.org/10.1007/978-3-658-09793-6_3

Witzel, A., \& Kühn, T. (1999). Berufsbiographische Gestaltungsmodi: Eine Typologie der Orientierungen und Handlungen beim Übergang in das Erwerbsleben (Arbeitspapiere No. 61). Bremen.

Witzel, A., \& Reiter, H. (2012). The Problem-Centred Interview: Principles and Practice. London: Sage. https://doi.org/10.4135/9781446288030

Zimmermann, E., \& Skrobanek, J. (2015). "Glaube an dich, dann schaffst du es auch?!" - Die Rolle der allgemeinen Selbstwirksamkeitsüberzeugung im Ausbildungsübergang. Zeitschrift Für Erziehungswissenschaft. (18 (2)), 351-374. https://doi.org/10.1007/s11618-015-0616-8

Zinnecker, J. (1991). Jugend als Bildungsmoratorium: Zur Theorie des Wandels der Jugendphase in westund osteuropäischen Gesellschaften. In W. Melzer, L. Liegle, W. Heitmeyer, \& J. Zinnecker (Eds.), Jugendforschung. Osteuropäische Jugend im Wandel: Ergebnisse vergleichender Jugendforschung in der Sowjetunion, Polen, Ungarn und der ehemaligen DDR (pp. 9-25). Weinheim: Juventa-Verlag. 
30 Capturing agency in different educational settings 